\title{
Cyclic AMP-Dependent Transcription Factor ATF-1
}

National Cancer Institute

\section{Source}

National Cancer Institute. Cyclic AMP-Dependent Transcription Factor ATF-1. NCI

Thesaurus. Code C92179.

Cyclic AMP-dependent transcription factor ATF-1 (271 aa, $\sim 29 \mathrm{kDa}$ ) is encoded by the human ATF1 gene. This protein is involved in the regulation of transcription. 